\title{
On the Analysis of Masonry Structures without box behavior
}

\author{
Paulo B. Lourenço, Nuno Mendes, Luís F. Ramos, Daniel V. Oliveira \\ Professor, ISISE, Department of Civil Engineering, University of Minho, 4800-058 Azurem, Guimarães, \\ Portugal, Tel. (+351) 253510209, Fax. (+351) 253510217, pbl@civil.uminho.pt.
}

\section{Short Title: Analysis of Masonry structures without box behavior}

\begin{abstract}
Assessment of the seismic performance of structures is still challenge. Historic masonry structures exhibit peculiar properties (low tensile strength and lack of box behavior) that make the task of the analyst even more difficult. It seems that traditional design and assessment methods, similar to the ones currently used for reinforced concrete structures, are not applicable.

This paper provides a review of the seismic analysis of masonry structures without box behavior. Different methods of structural analysis are discussed and a comparison is made between pushover methods and non-linear dynamic analysis with time integration. Three cases studies (S. Torcato church, Qutb Minar and "Gaioleiros" buildings) were used and the results show that traditional, adaptive or modal pushover analyses are not totally in agreement with non-linear dynamic analysis or experimental observations, namely cycle and rigid block behavior (rocking) and the out-of-plane behavior.
\end{abstract}


Keywords: masonry structures, box behavior, seismic performance, static and dynamic nonlinear analysis.

\section{Introduction}

The seismic behavior of ancient masonry buildings is particularly difficult to characterize and depends of several factors, namely the materials properties, the geometry of the structure, the connections between structural and non-structural elements, the stiffness of the horizontal diaphragms and conservation of its elements.

Masonry is a heterogeneous material that consists of units and joints. Units are such as bricks, blocks, ashlars, adobes, irregular stones and others. Mortar can be clay, bitumen, chalk, lime/cement based mortar, glue or other. The huge number of possible combinations generated by the geometry, nature and arrangement of units as well as the characteristics of mortars raises doubts about the accuracy of the term "masonry". Nevertheless, the mechanical behavior of the different types of masonry has generally common features: high specific mass, low tensile and shear strengths and low ductility (brittle behavior). In general, the ancient masonry structures were designed for vertical static loads (compressive behavior) not taking into account the high inertial loads caused by earthquakes.

The simplicity and the regularity in-plane as well in elevation (geometry, mass and stiffness distribution) are aspects that improve the seismic performance of the structures, preventing the local damage and decreasing the torsional effects. These criteria are presented in the design recommendations of the modern codes (Slak and Kilar, 2003). In general, the masonry buildings are composed by load-bearing walls, in which its dimensions in-plane are significantly higher than the thickness. It means that seismic performance of the load-bearing walls depends a lot on the application direction of the horizontal load. Furthermore, the geometry has also an important rule on seismic behavior of walls with openings, which can be 
divided in three structural elements: piers, lintels and "nodes". The in-plane dimensions of these elements are related with its slenderness and, consequently, with the type of in-plane collapse mechanism developed under seismic action (rocking, sliding, diagonal tension and toe crushing).

The in-plane stiffness of the masonry elements is significantly higher than its out-of-plane stiffness. Thus, seismic performance of ancient masonry buildings also depends on the capability to redistribute the horizontal loads between the elements, exploring the maximum in-plane strength of the walls and preventing the out-of-plane mechanisms. Here, the connection between orthogonal walls, the flexibility of the horizontal diaphragms and its connection to the masonry walls are the mainly factors to take into account for the capability to redistribute the seismic loads. Furthermore, when the partition walls, usually assumed as non-structural elements, are well connected to the load-bearing walls, also contribute for the global seismic performance of masonry structures.

This communication presents three cases studies of unreinforced masonry structures (S. Torcato church, Qutb Minar and "Gaioleiros" buildings). These structures have very different characteristics, namely in terms of mass and stiffness distribution. However, they present a common aspect of the historical buildings. In general, the historical buildings not present stiff floors able to provide diaphragmatic action, the so-called "box behavior". This type of structures have shown poor performance in many past earthquakes, see Figure 1.

Research conducted on flexible diaphragms, e.g. Brignola et al. (2008), Yi (2004), Paquette and Bruneau (2000) and Tomaževič et al. (1996), showed that flexible diaphragms provide the following results: (a) supports at floors to behave as a spring support; (b) large deformation capacity and high strength of the floor with respect to its mass. Failure mechanisms of flexible diaphragms are related to the lack or weak connections between the masonry walls and diaphragms; (c) highly non-linear hysteretic behavior when peak ground 
acceleration is high; (d) strengthening of the horizontal diaphragms as a natural solution even if an increase of the in-plane stiffness per se is not enough to improve the global response of the building.

The seismic performance of the cases of study was assessed through different techniques of structural analysis, namely limit analysis using macro-blocks, pushover analyses with several load distributions and non-linear dynamic analysis wit time integration by using the Finite Element and Rigid Methods.

\section{S. Torcato church, Portugal}

$\mathrm{S}$. Torcato church (Figure 2) is located in the village of S. Torcato, $7 \mathrm{~km}$ north from the city of Guimarães (Portugal). The church combines several architectonic styles, namely Classic, Gothic, Renaissance and Romantic. The construction started in 1871 and is being now finalized. The dimensions are large: the main nave has $57.5 \times 17.5 \mathrm{~m}^{2}$ and $26.5 \mathrm{~m}$ height; the transept has $37.1 \times 11.4 \mathrm{~m}^{2}$; and the bell-towers have a cross section equal to $7.5 \times 6.3 \mathrm{~m}^{2}$ with, approximately, $50 \mathrm{~m}$ height. The oldest part of the church, from the towers up to the transept, is built in masonry with locally available natural granite stones and three leaf walls. Limit analysis using macro-blocks was carried out for the seismic performance assessment, as the church exhibits significant damage and requires strengthening. In existing masonry buildings partial collapses often occur due to seismic action, generally, with the loss of equilibrium of rigid bodies. Seismic assessment with the $q$ factor (linear kinematic analysis) is

fulfilled if the spectral acceleration $a_{0}{ }^{*}$ that activates the mechanism satisfies the following inequality (OPCM 3274, 2003): 


$$
a_{0}^{*} \geq \frac{a_{g} S}{q}\left(1+1.5 \frac{Z}{H}\right)
$$

where: $a_{g}$ is the ground acceleration; $S$ is the soil factor; $Z$ is the height from the building foundation to the centre of gravity of the weight forces, whose masses generate horizontal forces and which are not transmitted to the other parts of the building; $H$ is the total height of the building from the foundation; $q$ is the behavior factor.

In this case study, four mechanisms were defined, based on the inspection and structural analysis of the structure (Lourenço and Ramos, 2002). The mechanisms were partially marked by existing cracks. Figure 3 shows the mechanisms considered in the limit kinematic analysis. According to the limit analysis, the church is safe and the lowest safety factor is equal to 1.69 (with overturning of the tympanum).

In Table 1 the parameters considered in the analysis are presented $\left(\alpha_{0}\right.$ is the load multiplier that activates the local damage mechanism; $\mathrm{M}^{*}$ is the participating mass; $\mathrm{e}^{*}$ is the fraction of the participating mass; $\mathrm{a}_{0}{ }^{*}$ is the spectral acceleration; FS is the safety factor).

This analysis method is conceptually simple and an abacus of possible mechanisms is available at (OPCM 3274, 2003). In the present case, the method is easy to apply as the collapse mechanisms are also partially defined by existing cracking. It is believed that the benefits of using collapse mechanism analysis are the following: (a) the method is intuitive and does not requires advanced knowledge of physics or mechanics, being therefore at reach of most practitioners; (b) the abacus of possible collapse mechanisms and the observation of previous collapses under earthquake action provide are the basis of the inductive approach; (c) the method is conceptually and analytically correct, if the proper collapse mechanisms are selected. It is believed also the method possesses a strong drawback: if wrong collapse mechanisms are selected, the seismic assessment (and related strengthening measures, if 
applicable) is meaningless. Therefore, practitioners must ensure correct selection of collapse mechanism, either by a detailed inspection of the structure being studied or by adopting more sophisticated analysis methods. This is certainly the case of complex or unusual structures, for which the mechanisms might not be obvious. Another example would be to use pushover analysis or time integration analysis to get more confidence on collapse mechanisms and then adopt the correct collapse mechanism analysis to calculate the required strengthening.

The issue of adopting more sophisticated methods of analysis is therefore addressed in the next sections.

\section{Qutb Minar in New Delhi, India}

The Qutb Minar (Figure 4a) is the highest monument of India and one of the tallest stone masonry towers in the world, dating from the $13^{\text {th }}$ century. The cross-section is circular/polilobed, being the base diameter equal to $14.07 \mathrm{~m}$ and tapering off to $3.13 \mathrm{~m}$ at the top, over a height of $72.45 \mathrm{~m}$ (Figure $5 \mathrm{~b}$ ). The tower is composed by an external shell corresponding to a three leaf masonry wall and a cylindrical central core (Chandran, 2005). The core and the external shell of the tower are connected by a helicoidal staircase and by 27 "bracings" stone lintels. The staircase is spiral, disposed around the central masonry shaft, and it is made of Delhi quartzite stone. Each storey has a balcony and the uppermost storey finishes with a platform.

To evaluate the seismic performance of the Qutb Minar different techniques of structural analyses were used, namely non-linear dynamic analysis and non-linear static analysis (pushover analysis). In the analyses different numerical models were considered. Two models were prepared using the Finite Element Method (FEM), both are three-dimensional models 
but one uses 3D solid elements (Solid Model) while the other one was performed with 3D composite beams (Beam Model). A simplified in-plane model of the minaret based on the Rigid Element Method was also developed. The Rigid Element Method idealizes the masonry structure as a mechanism made of rigid elements and springs (Casolo and Peña, 2007). The numerical models were updated from dynamic identification tests (Ramos et al., 2006).

In the FEM models, the physical non-linear behavior of the masonry was simulated using the Total Strain Crack Model detailed in (DIANA, 2005), with non-linear behavior given by a parabolic law in compression and an exponential law in tension (fixed crack model with variable shear retention). In the rigid body and spring model (RBSM), the constitutive law for axial springs is parabolic in compression and bi-linear in tension with softening. A Mohr Coulomb law was considered for shear springs in order to relate the shear stresses with the axial stresses. Complete details on the analysis can be found in (Peña et al., 2009), where it is shown that small difference are found between all the models considered in the pushover analysis and in model updating.

The dynamic analyses were carried out using five artificial accelerograms compatible with the elastic response spectrum of the Indian Seismic code (Indian Standard, 1983) for Delhi (PGA $=0.20 \mathrm{~g})$. Figure 5 shows the maximum seismic coefficient (Eq. 2), calculated from the top of the structure to the level $i$, and displacements for each level with the Beam Model. It is stressed that the adopted definition represents the envelope for each section and no discussion is made here on the distribution of mass above a given section. The average seismic coefficient at the base is 0.16 , with an increase to 0.18 for the first level. The second balcony has an average seismic coefficient of 0.28 , while the third and fourth balconies have an average seismic coefficient of 0.47 and 0.9 , respectively. It means that the relation between the horizontal forces (instabilizing forces) and the self weight (stabilizing forces) increase along the height of the minaret. Furthermore, it is noted that the cross-section of the structure 
decrease in elevation. Displacements (Figure 5b) of levels 1 to 3 increase almost linearly, while displacements of level 5 are almost the double of the displacements of level 4 ( 0.35 to $0.65 \mathrm{~m}$ ). Based on forces (seismic coefficient) or deformation (maximum displacement), the results of the non-linear dynamic analysis indicate that levels 4 and 5 are the most vulnerable, where the behavior of level 5, with maximum drift equal to $3.0 \%$, is highlighted.

$$
\alpha_{i}=\frac{\sum \text { Horizontal loads }_{i}}{\sum \text { Self weight }_{i}}
$$

Pushover analyses were carried out considering a uniform acceleration distribution. The load was applied with increasing acceleration in the horizontal direction and a control point at the top of the tower was considered. Figure 6a shows the capacity curves (lateral displacement seismic coefficient at the base level). Similar behavior was found with the different models. It can be observed that the average seismic factor is 0.20 and the minaret collapses by overturning at the base.

In order to study the influence of the distribution of the lateral load in the pushover analysis, additional non-linear static analyses were performed. Four different configurations of lateral loads were considered: (a) linear distribution of the displacement along the height; (b) loads proportional to the first modal shape; (c) adaptive pushover analysis, changing the load distribution according to the changes in the first modal shape during the analysis; (d) modal pushover analysis (Chintanapakdee and Chopra, 2003). The results of the pushover analyses do not change qualitatively from what is shown in Figure 6a and the failure mode and displacements' distribution along the height are not in agreement with the non-linear dynamic analysis. Even model pushover analysis, in which the responses of the first seven modes were 
combined, is not able to simulate the amplification of the response at higher levels (Figure $6 b)$.

\section{4. “Gaioleiro" building in Lisbon, Portugal}

The "gaioleiro" buildings (Figure 7) were developed between the mid $19^{\text {th }}$ century and beginning of the $20^{\text {th }}$ century, mainly in the city of Lisbon (Portugal), and remains still much in use nowadays. These buildings characterize a transition period from the anti-seismic practices used in the "pombalino" buildings originated after the earthquake of 1755 (Ramos and Lourenço, 2004), and the modern reinforced concrete frame buildings. These buildings are four to six stories high with masonry walls and timber floors and roof. The external walls are, usually, in rubble masonry with lime mortar.

In order to assess the seismic vulnerability of the "gaioleiro" buildings, shaking table tests were carried out at the 3D shaking table of National Laboratory of Civil Engineering (LNEC), Lisbon (Candeias et al., 2004). A prototype of an isolated building was defined, constituted by four storeys with an interstory height of $3.60 \mathrm{~m}$, and two opposite façades with a percentage of openings equal to $28.6 \%$ of the façade area, two opposite gable walls (with no openings) and timber floors. Due to the size and payload of the shaking table, the mock-ups (Figure 8) were built using a 1:3 reduced scale, taking in account Cauchy's law of similitude (Carvalho, 1998). In plant, the mock-up has $3.15 \times 4.15 \mathrm{~m}^{2}$ and interstory height is equal to $1.2 \mathrm{~m}$. The walls, originally built in poor quality rubble masonry with lime mortar, were replaced by a self compacting bentonite-lime concrete. The thickness of the walls is equal to $0.15 \mathrm{~m}$. In the construction of the timber floors, medium-density fiberboard (MDF) panels connected to a set of timber joists, oriented in the direction of the shortest span, were used. The panels were cut in rectangles stapled to the joists, keeping a joint for separating the panels. 
The methodology for seismic vulnerability assessment was based on the identification of the dynamic properties of the mock-ups along a series of seismic tests with increasing input excitations. The seismic tests were performed by imposing accelerograms with increasing amplitude in two uncorrelated orthogonal directions. The dynamic properties of the structures were identified through forced vibration testing at the shaking table before the first seismic test and after each of the seismic tests. For detailed information about the results of the dynamic tests, see (Candeias, 2009).

In the numerical modeling non-linear dynamic and pushover analyses were performed. The numerical model was prepared, on the 1:3 reduced scale, using the Finite Element Method (FEM) implemented in the software DIANA (2005), by using shell elements for the simulation of the walls and three dimensional beam elements for the timber joists, all based on the theory of Mindlin-Reissner. In the modeling of the floors, shell elements were also used with the purpose of simulating the in plane deformability. A quantitative calibration based on the natural frequencies obtained in the first characterization test was done. Moreover, the non-linear behavior of the numerical model was validated (qualitative calibration), taking into account the crack pattern obtained after the final seismic test (Figure 9). The numerical model is able to simulate the cracking of the lintels, which is mainly associated to the in-plane behavior, and the horizontal cracks at piers of the higher floor, caused by the out-of-plane shaking, observed in the tests. Here, only brief results of the numerical analyses are presented, see (Mendes and Lourenço, 2010) for full details.

\subsection{Non-linear dynamic analysis}

In the non-linear dynamic analysis the horizontal seismic action was described by two orthogonal and independent components, represented by the same response spectrum. Three earthquakes were used, composed of two uncorrelated artificial accelerograms, compatible 
with the elastic response spectrum (type 1) defined by the National Annex of EC8 (EN 19981, 2004), for the zone of Lisbon.

Due to the fact that non-linear dynamic analyses are very time consuming and the response spectrum of type 1 (interplate earthquake) is usually more stringent for Lisbon and for the type of structures being considered, only one type of earthquake was considered. Using the 1:3 reduced scale, the accelerograms have a total duration of $6 \mathrm{~s}$, from which $3.33 \mathrm{~s}$ correspond to the intense phase, and a $P G A$ equal to $4.51 \mathrm{~m} / \mathrm{s}^{2}$. Unlike tests, which the seismic action were applied with increasing amplitude, in the numerical analysis the earthquakes were applied directly at structure base with a factor equal to one.

Figure 10 presents the maximum values of the principal tensile strains $\varepsilon_{l}$ for the three earthquake records. The results indicate that the façades at the $4^{\text {th }}$ floor and at the base of the structure are the zones of larger damage concentration, being the high level of damage in the $4^{\text {th }}$ floor's piers highlighted. Figure 11 presents the maximum displacement in the middle of the walls, in which the out-of-plane mechanism of the piers is clearly observed.

\subsection{Pushover analyses}

Two distributions of lateral loads were used for the pushover analysis: (a) uniform pattern, based on lateral forces proportional to mass regardless of elevation - uniform response acceleration; (b) modal pattern, proportional to forces consistent with the $1^{\text {st }}$ mode shape in the applied direction.

In the capacity curves of the pushover analyses proportional to the mass (Figure 12), the maximum seismic coefficients are higher than the dynamic analysis (about 24\%) and the damage concentration only appears at the lower zone of the structure. It is noted that in the dynamic analysis the damage concentrates at the $4^{\text {th }}$ floor (façades) and at the base. Thus, this 
pushover analysis does not simulate correctly the performance of structure under seismic load.

The capacity curves of the pushover analysis proportional to the $1^{\text {st }}$ mode (in the applied direction) show that the maximum load capacity approach the dynamic analysis. As expected, the crack patterns only provide in plane damage (Figure 13), which is not in agreement with the out-of-plane mechanism found in the time integration analysis and shaking table test (Figure 9 and 10).

In an attempt to explore the pushover analyses, two adaptive analyses were performed (Figure 12). In the first adaptive pushover analysis, the lateral loads, proportional to the $1^{\text {st }}$ mode shape in were applied independently by direction and were updated as a function of the existing damage. The aim was to understand how the update of the external load vector can influence the structure response. However, this analysis did not provide any improvement in terms of load-displacement diagrams or failure mechanisms (Mendes and Lourenço, 2010). Finally, in the second adaptive pushover analysis the lateral loads, proportional to the $1^{\text {st }}$ mode shape in the applied direction, were applied simultaneously in the transversal and longitudinal direction in the relation $30 \%$ and $100 \%$, respectively. Here, the aim was to obtain the in-plane and the out-of-plane damage together in the same analysis. However, the combined effect of the loads applied simultaneously in the two directions cause the damage concentration on lintels, not simulating correctly the performance of structure under seismic load (Mendes and Lourenço, 2008). Thus, the usually adopted pushover analyses did not simulate correctly behavior of the "gaioleiro" buildings under seismic load, namely the outof-plane behavior.

\section{Discussion of the results and conclusions}


In this paper seismic performance of three unreinforced masonry structures without box behavior (S. Torcato church, Qutb Minar and "Gaioleiros" buildings) was assessed, by using different techniques of structural analysis.

S. Torcato church is a typical example of the historical constructions with high and thick stone masonry walls without horizontal diaphragms able to decrease its out-of-plane slenderness and efficiently redistribute the seismic action by the walls. Furthermore, the church presents regularity in plant and elevation. The past earthquakes have shown that the damaged occurred in this type of structures is mainly related with the collapse of structure portions (macro-blocks). Thus, the limit analysis using macro-blocks was used for seismic performance assessment of the S. Torcato church and four collapse mechanisms were defined. The analysis indicates that the structure is safe and the collapse mechanism of overturning of the tympanum presents the lowest safety factor (1.69).

The Qutb Minar can be simplified through a cantiviler beam with variable mass and stiffness in elevation. The cross-section is composed by five masonry layers. The results of the nonlinear dynamic analysis (beam and RBSM models) are in agreement with the historical damage caused by earthquakes, leading to the conclusion that the last two floors are the most vulnerable part of the minaret. The pushover analyses (proportional to the mass and first modal shape, adaptive and multi-modal) are no in agreement with the results of the non-linear dynamic analysis, indicating that the minaret collapses by overturning at the base.

The "gaioleiro" building typology probably presents the highest vulnerability of the housing stock of Portugal. These buildings are four to six stories high, masonry façades with openings, masonry gable with no openings and timber floors and roof. Unreinforced masonry buildings with flexible can be also found in others European countries. In this case study a prototype of the typology was defined and the seismic performance was assessed through shaking table tests and numerical analyses. The results of the tests and non-linear dynamic analysis with 
time integration showed that the damage concentrates on the façades, in which the cracking of the lintels and the horizontal cracks at piers of the higher floor is highlighted. Once more, the pushover analyses carried out were no able to simulate correctly all mechanism observed, namely the in-plane rocking and out-of-plane shaking of the of the higher floor piers. The pushover analyses proportional to the $1^{\text {st }}$ mode provided a good estimation of the load capacity compared with the dynamical analysis. These analyses could be an alternative to the dynamical analysis to simulate the global in plane behavior of the structure. However, the outof-plane mechanism (first mechanisms) should be analyzed separately using limit analysis with macro-blocks.

In case of seismic loading, it is certain that non-linear behavior is triggered at early stages of loading and linear elastic analysis seems not an option. Moreover, stiff floors able to provide diaphragmatic action, the so-called "box behavior", are usually not present in historic buildings. Therefore, the traditional design and assessment method of modal superposition, possibly with a 3-degree-of-freedom system per floor, is not applicable. The non-linear dynamic analysis with time integration is a complex and time consuming tool hardly available for practitioners. The alternative options seem to be non-linear static methods, as recommended in most codes for earthquake safety assessment, or the limit analyses using macro-blocks.

Despite the strong capabilities of limit analysis and the existence of abacus of possible mechanisms, it is believed that the selection of adequate collapse mechanism is complex and requires a careful in situ inspection. The experience and structural capacity of the practitioner are subjected to a significant demand, as the process is difficult to control and the selection of erroneous mechanisms might result in totally incorrect structural assessment and remedial measures. 
Several types of non-linear static analyses have been proposed, namely proportional to the mass and first mode shape (EN 1998-1, 2004), adaptive (Casarotti and Pinho, 2007) and modal (Chopra and Goel, 2002). However, the application of these methods to the unreinforced masonry buildings without box behavior should be use with caution and more research should be provide, namely for structures that presents cycle and rigid block behavior (Krstevska et al., 2008).

The hybrid frequency time analysis method (DIANA, 2005) is a combination of a modal response frequency analysis and non-linear transient analysis should be tested for unreinforced masonry buildings without box-behavior in some future work.

\section{Acknowledgements}

The present work is partly funded by FCT (Portuguese Foundation for Science and Technology), through project POCI/ECM/61671/2004, "Seismic vulnerability reduction of old masonry buildings" and project PTDC-ECM-68188-2006, "Innovative solutions for nonload bearing masonry infills".

\section{References}

Brignola, A., Podestà, S. and Pampanin, S. 2008. In-plane stiffness of wooden floor. New Zealand Society for Earthquake Engineering Conference.

Candeias, P. 2009. Seismic vulnerability assessment of masonry buildings. PhD Thesis, University of Minho, Portugal (in Portuguese). Available from www.civil.uminho.pt/masonry 
Candeias, P., Costa, A. C. and Coelho, E. 2004. Shaking table tests of 1:3 reduced scale models of four unreinforced masonry buildings. 13th World Conference on Earthquake Engineering, Vancouver, Canada.

Carvalho, E. C. 1998. Seismic testing of structures. 11th European Conference on Earthquake, Parris, France, Rotterdam: AA Balkema.

Casarotti, C. and Pinho, R. 2007. An adaptive spectrum method for assessment of bridges subjected to earthquake action. Bulletin of Earthquake Engineering, 3: 377-390.

Casolo S. and Peña, F. 2007. Rigid element model for in-plane dynamics of masonry walls considering hysteretic behaviour and damage. Earthquake Engineering and Structural Dynamics, 21 (2):193-211.

Chandran, S. 2005. Numerical analysis of monumental structures. MSc Thesis. Indian institute of Technology Madras.

Chintanapakdee, C. and Chopra, A. K. 2003. Evaluation of modal pushover analysis using generic frames. Earthquake Engng Struct. Dyn., 32:417-442.

Chopra, A. K. and Goel, R. K. 2002. A modal pushover analysis procedure for estimating seismic demands for buildings. Earthquake Engineering and Structural Dynamics, 21: 561582.

DIANA, 2005. DIsplacement method ANAlyser", release 9.1, cd-rom, Netherlands.

EN 1998-1 2004. Eurocode 8: Design of structures for earthquake resistance - General rules, seismic actions and rules for buildings.

Indian Standard 1983. Criteria for earthquake resistant design of structures - Part 1.

Krstevska, L., Tashkov, Lj., Gramatikov, K., Landolfo, R., Mammana. O., Portioli, F. and Mazzolani, F. M. 2008. Shaking table tests on the large scale model of Mustafa Pasha Mosque without and with FRP. Structural Analysis of Historic Construction, London, pp. 383-391. 
Lourenço, P. B. and Ramos, L. F. 2002. Inspection and analysis of a $19^{\text {th }}$ century sanctuary in São Torcato, Portugal. $7^{\text {th }}$ International Seminar on Structural Masonry for the Developing Countries, Belo Horizonte, Brazil (in Portuguese). Available from www.civil.uminho.pt/masonry

Mendes, N. and Lourenço, P. B. 2008. Reduction of the seismic vulnerability of ancient buildings. Activity report of the project: POCI/ECM/61671/2004, FCT (in Portuguese). Available from www.civil.uminho.pt/masonry.

Mendes, N. and Lourenço, P. B. 2010. Seismic assessment of masonry "Gaioleiros" buildings in Lisbon, Portugal", Journal of Earthquake Engineering, 14: 1, 80-101.

OPCM 3274 2003. Initial items on the general criteria for seismic classification of the national territory and technical regulations for buildings in earthquake zone. Italian standard. Buildings with masonry structure (chapter 8) and Existing masonry structure (chapter 11). English version.

Paquette, J. and Bruneau, M. 2000. Pseudo-dynamic testing of an unreinforced masonry buildings with flexible diaphragm. 12th World Conference on Earthquake Engineering, New Zealand.

Peña, F., Lourenço, P. B., Mendes, N. and Oliveira, D. V. 2009. Numerical models for the seismic assessment of an old masonry tower. Engineering Structures (accepted for possible publication).

Ramos, L. F. and Lourenço, P. B. 2004. Advanced numerical analysis of historical centers: A case study in Lisbon. Engineering Structures, 26:1295-1310.

Ramos, L. F., Casarin, F., Algeri, C. and Lourenço, P. B. 2006. Investigation techniques carried out on the Qutb Minar, New Delhi, India. Structural Analysis of Historical Constructions. Lourenço, Roca, Modena and Agrawal Eds. New Delhi, pp. 633-640. 
Slak, T. and Kilar, V. 2003. Initial conceptual design of earthquake resistant rlc and masonry buildings according to Eurocode 8. Earthquake Resistant Engineering Structures IV.

Tomaževič, M., Lutman, M. and Weiss, P. 1996. Seismic upgrading of old brick-masonry houses: tying of walls with steel ties”, Earthquake Spectra Journal, 12(3).

Yi, T. 2004. Experimental investigation and numerical simulation of an unreinforced masonry structure with flexible diaphragms. Thesis for the degree doctor of philosophy in civil and environmental engineering. Georgia Institute of Technology.

\section{List of Figures}

Figure 1 Examples of the URM buildings damage, Italy 2009: (a) residential building in Onna; (b) collapse of the dome of St. Massimo in L'Aquila.

Figure 2 S. Torcato church: (a) main façade; (b) lateral view; (c) plan.

Figure 3 Mechanisms: (a) overturning of the left tower; (b) overturning of the right tower; (c) 
Figure 4

Figure 5

Figure 6

Figure 7

Figure 8

Figure 9

Figure 10

Figure 11

Figure 12

Figure 13

overturning of the façade; (d) overturning of the tympanum. (FS is the safety factor) Qutb Minar: (a) general view; (b) dimensions (in meters).

Maximum absolute results along the height of the minaret for dynamic analyses with Beam Model: (a) seismic coefficient; (b) lateral displacement.

Result of the pushover analyses: (a) capacity curves of the pushover analyses proportional to the mass; (b) comparison between the drifts obtained through modal pushover analysis and trough dynamic analyses of the Beam and RBSM Models.

Examples of "Gaioleiro" buildings, Lisbon, Portugal.

General view of the mock-up.

Damage the model: (a) numerical; (b) experimental (Model 1).

( $\varepsilon_{l}$ is the principal tensile strain, which is an indicator of crack width)

Tensile principal stains (outside surface): (a) earthquake 1; (b) earthquake 2; (c) earthquake 3.

Maximum out-of-plane displacement in the middle of the: (a) façades; (b) gable walls.

Capacity curves of the pushover analyses: (a) transversal direction; (b) longitudinal direction.

(The silver pattern represents the envelope of the three dynamic analyses).

Tensile principal strains of the pushover analysis proportional to the $1^{\text {st }}$ mode in the: (a) transversal direction; (b) longitudinal direction. 


\section{List of Tables}

Table $1 \quad$ Parameters of the linear limit kinematic analysis. 


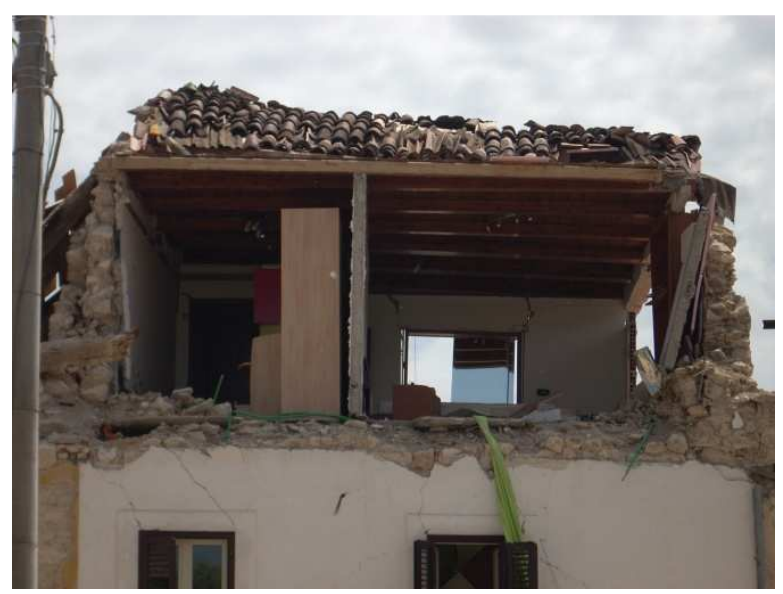

(a)

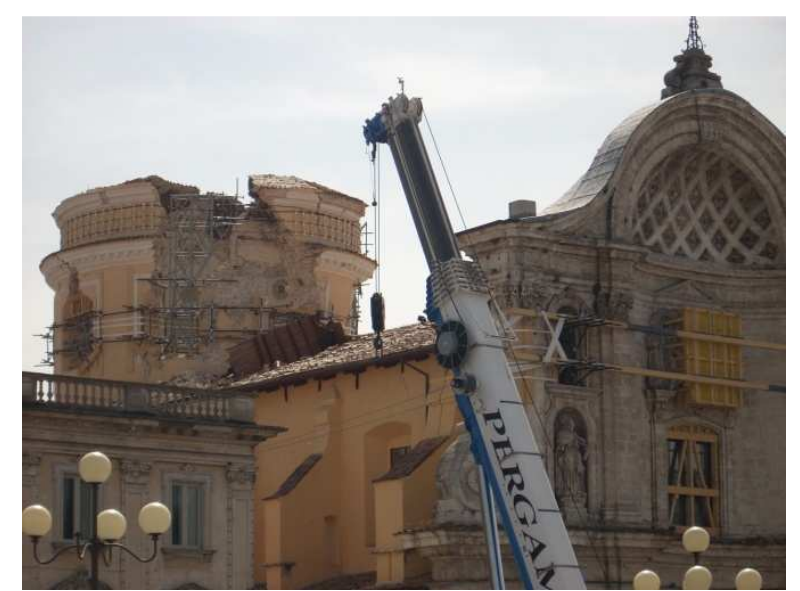

(b)

Figure 1: Examples of the URM buildings damage, Italy 2009: (a) residential building in Onna; (b) collapse of the dome of St. Massimo in L'Aquila. 


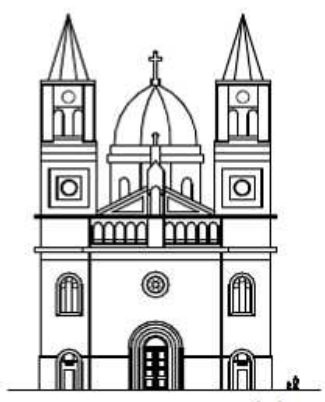

(a)

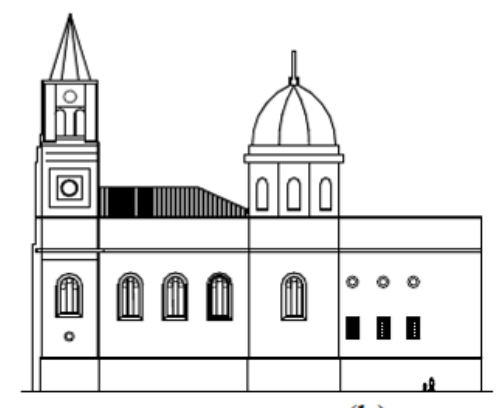

(b)

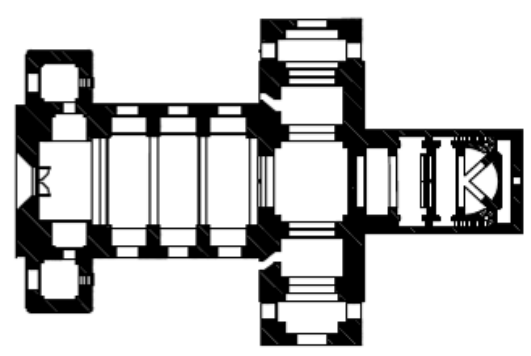

(c)

Figure 2: S. Torcato church: (a) main façade; (b) lateral view; (c) plan. 


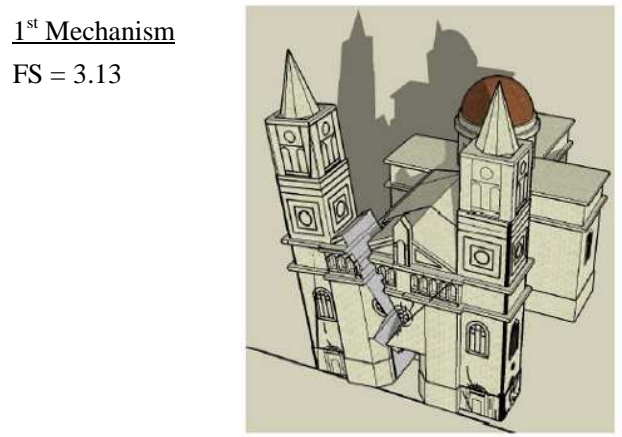

(a)

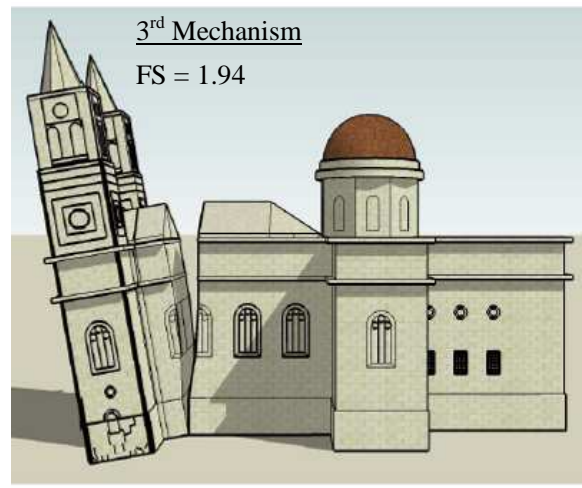

(c)

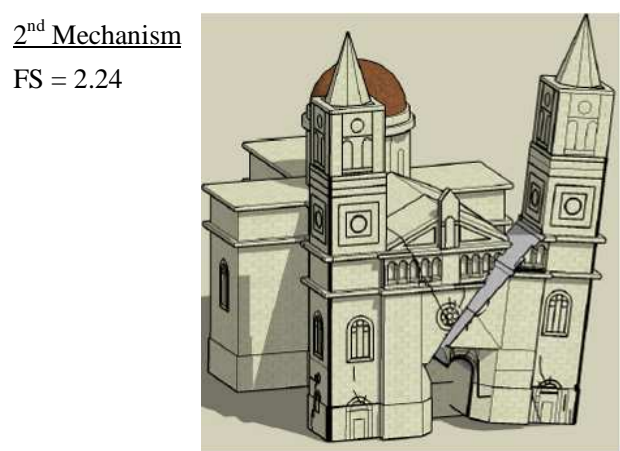

(b)

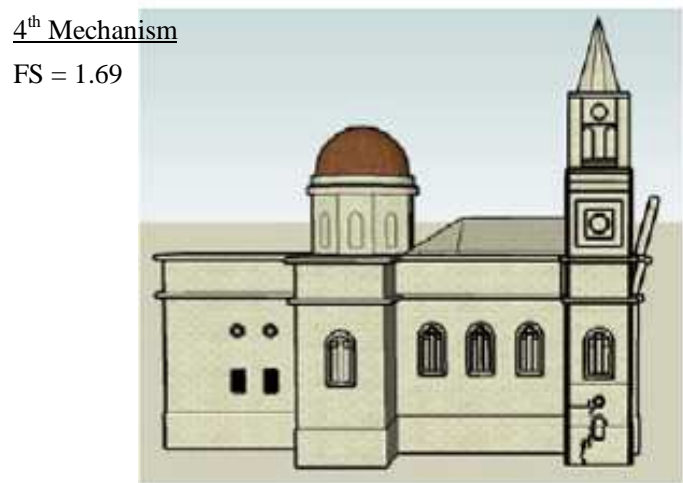

(d)

Figure 3: Mechanisms: (a) overturning of the left tower; (b) overturning of the right tower; (c) overturning of the façade; (d) overturning of the tympanum. (FS is the safety factor) 


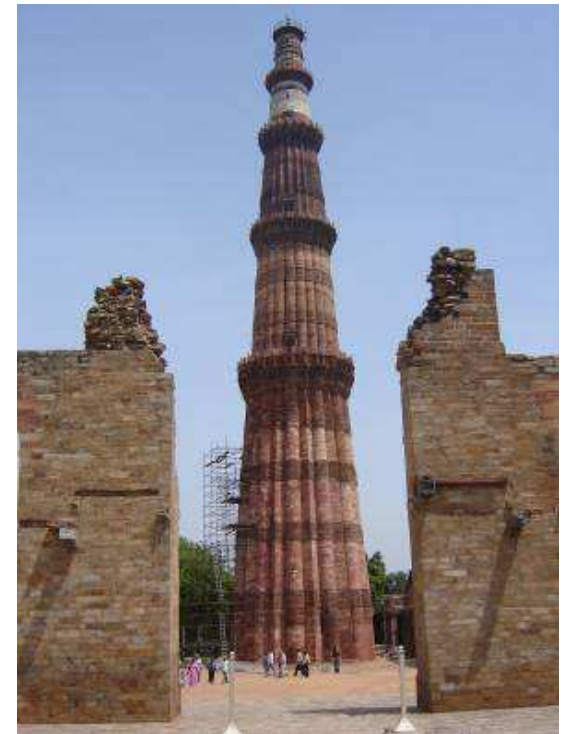

(a)

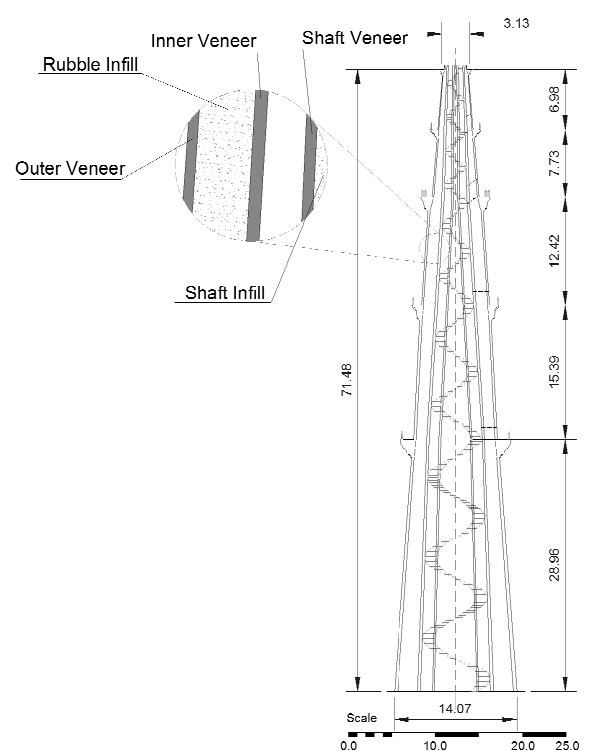

(b)

Figure 4: Qutb Minar: (a) general view; (b) dimensions (in meters). 


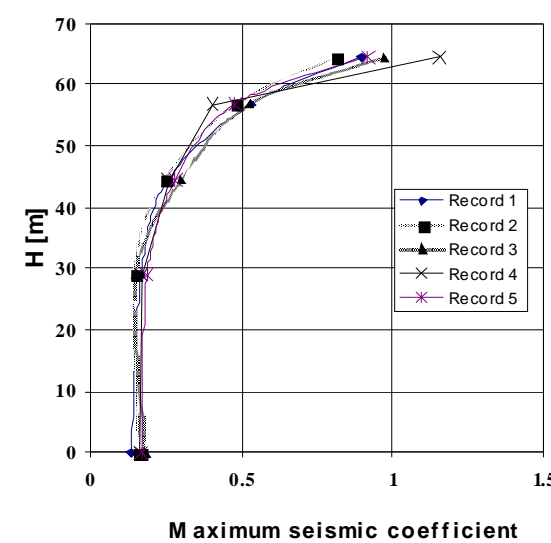

(a)

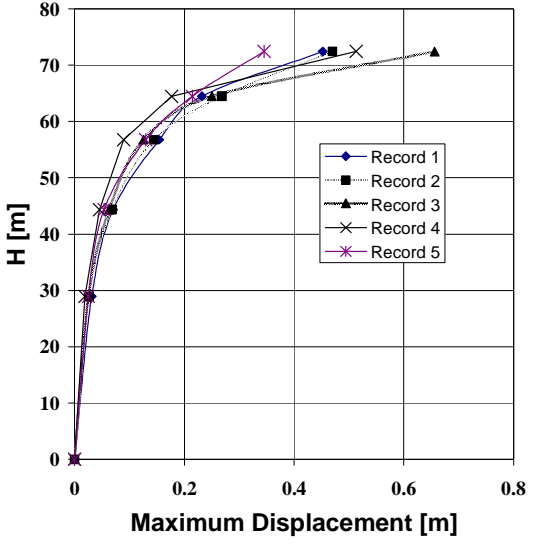

(b)

Figure 5: Maximum absolute results along the height of the minaret for dynamic analyses with Beam Model: (a) seismic coefficient; (b) lateral displacement. 


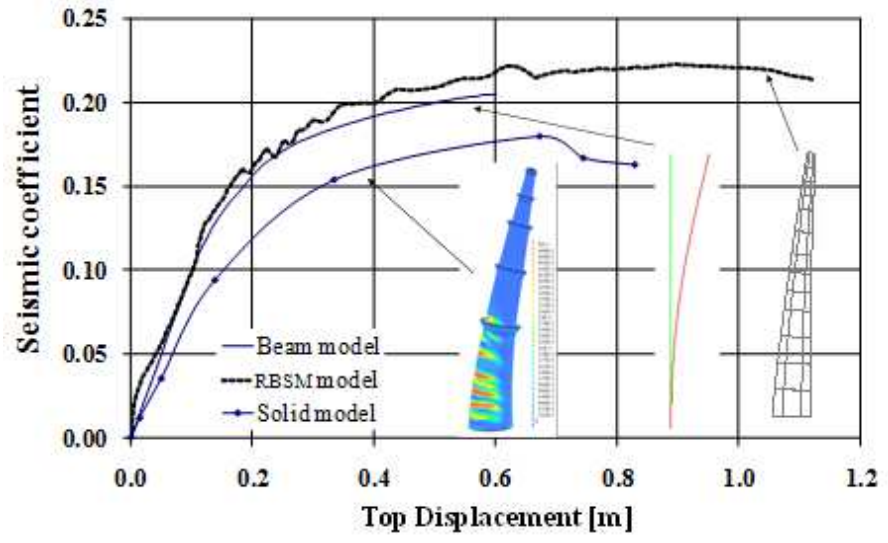

(a)

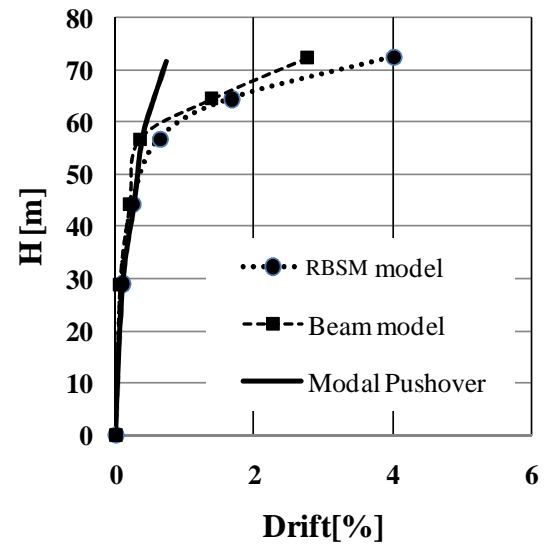

(b)

Figure 6: Results of the pushover analyses: (a) capacity curves of the pushover analyses proportional to the mass;

(b) comparison between the drifts obtained through modal pushover analysis and trough dynamic analyses of the Beam and RBSM Models. 

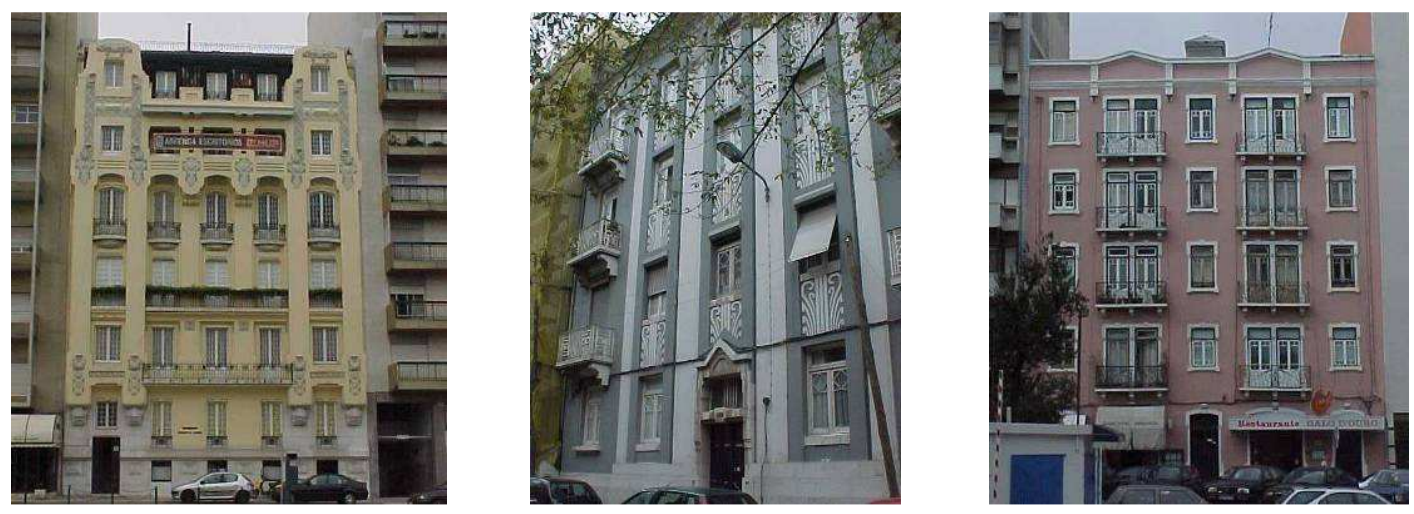

Figure 7: Examples of "Gaioleiro" buildings, Lisbon, Portugal. 


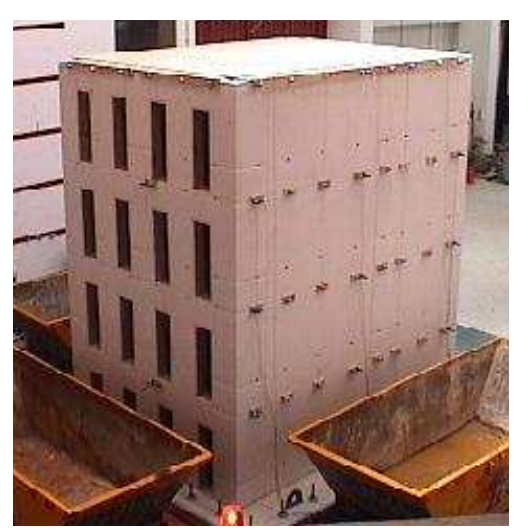

Figure 8: General view of the mock-up. 


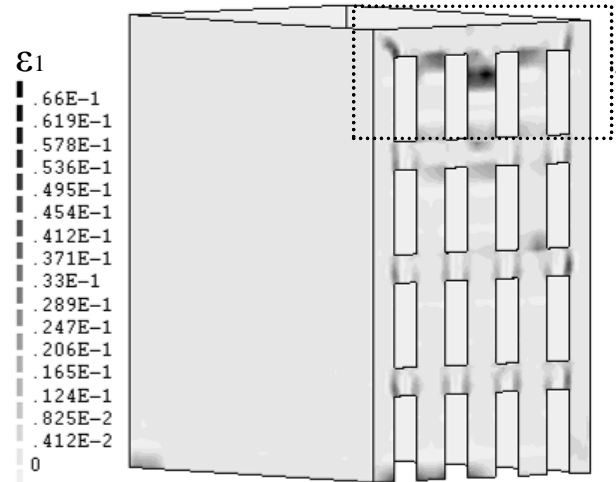

(a)

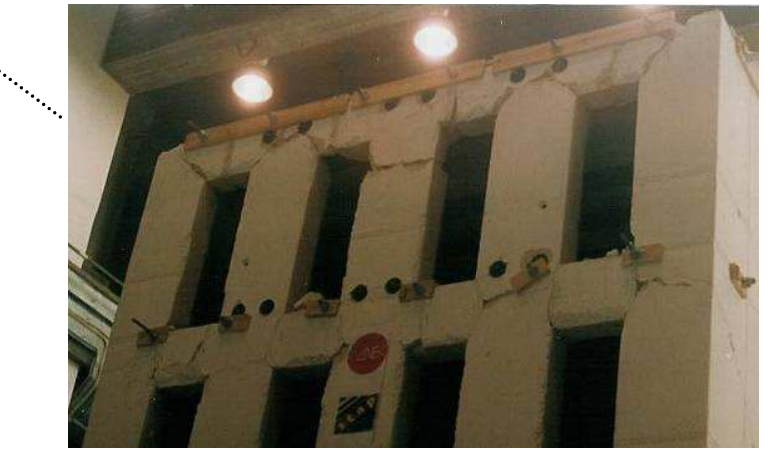

(b)

Figure 9: Damage the model: (a) numerical; (b) experimental (Model 1).

( $\varepsilon_{l}$ is the principal tensile strain, which is an indicator of crack width) 


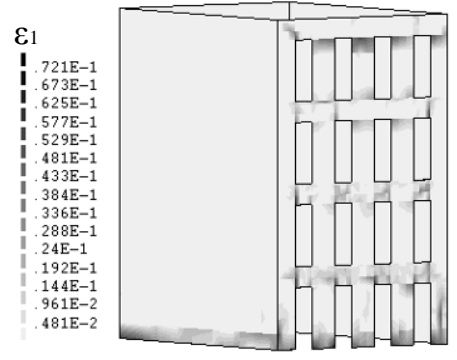

(a)

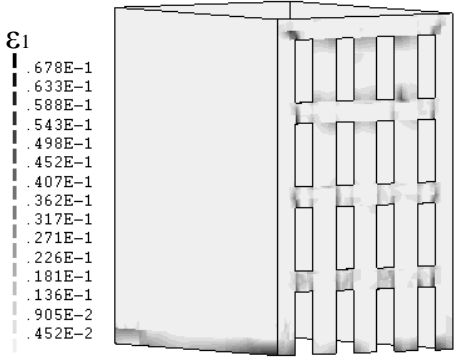

(b)

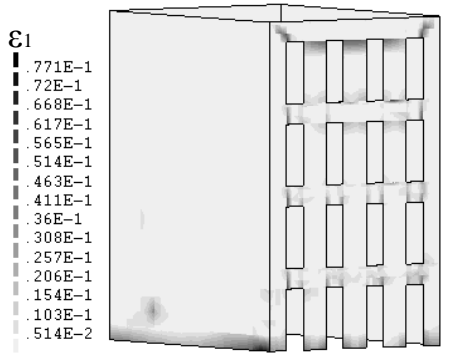

(c)

Figure 10: Tensile principal stains (outside surface): (a) earthquake 1; (b) earthquake 2; (c) earthquake 3. 


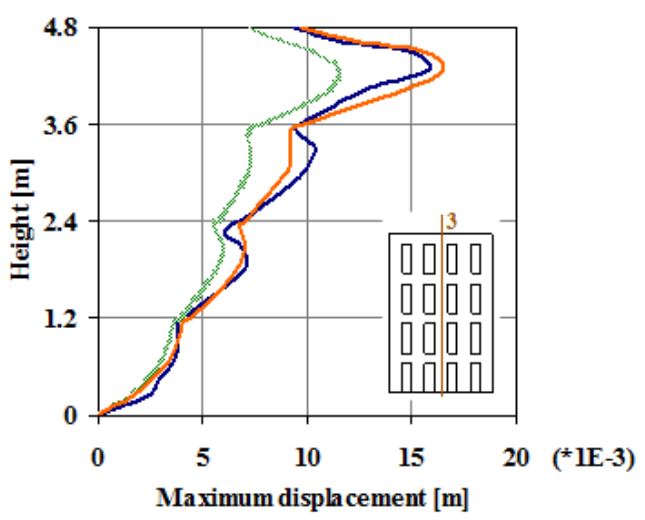

(a)

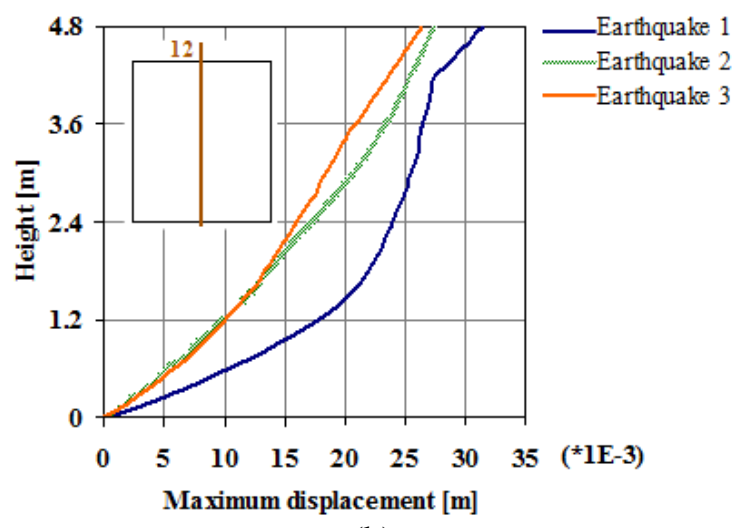

(b)

Figure 11: Maximum out-of-plane displacement in the middle of the: (a) façades; (b) gable walls. 


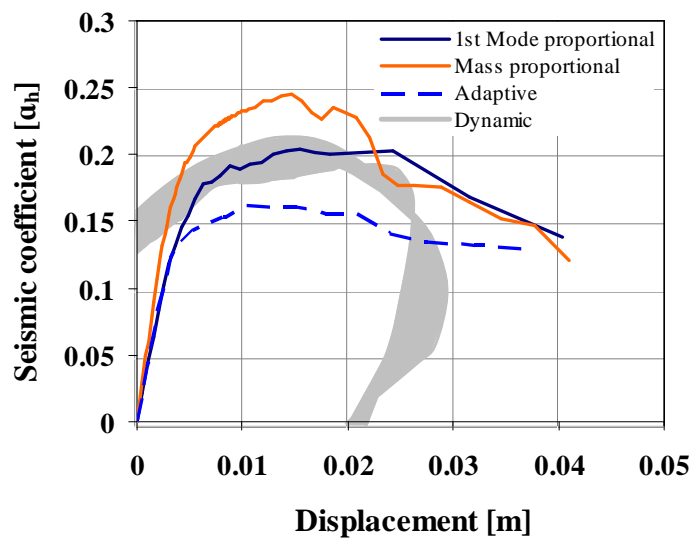

(a)

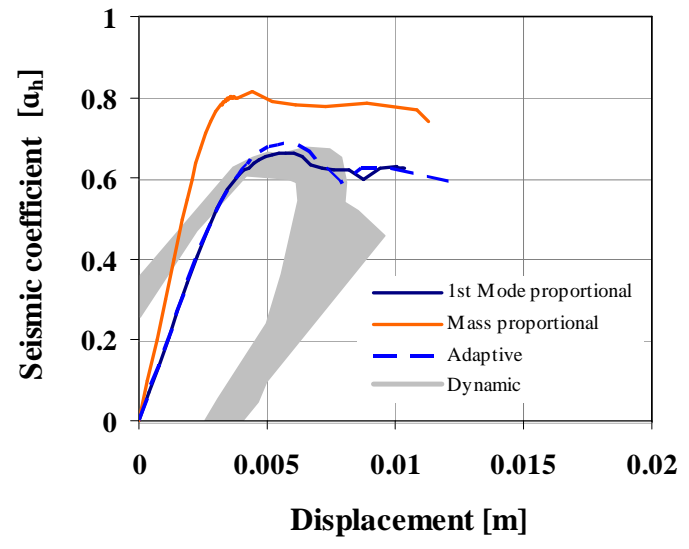

(b)

Figure 12: Capacity curves of the pushover analyses: (a) transversal direction; (b) longitudinal direction.

(The silver pattern represents the envelope of the three dynamic analyses). 


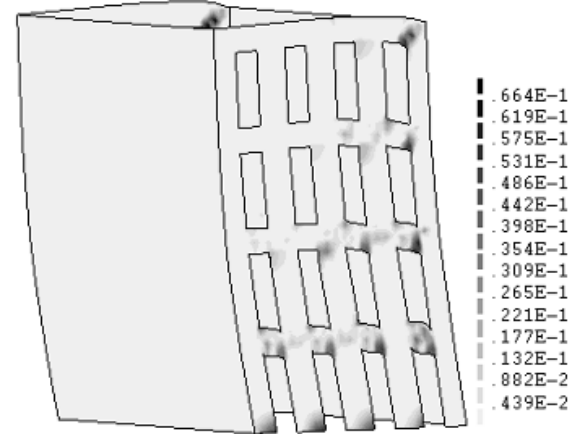

(a)

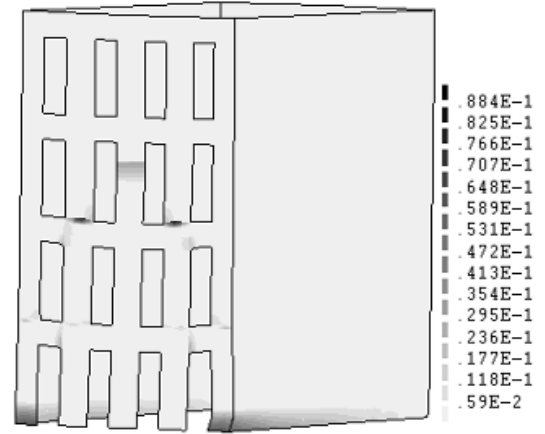

(b)

Figure 13: Tensile principal strains of the pushover analysis proportional to the $1^{\text {st }}$ mode in the: (a) transversal direction; (b) longitudinal direction. 
Table 1: Parameters of the limit kinematic analysis.

\begin{tabular}{lccccrr}
\hline & $\alpha_{0}$ & $\mathrm{M}^{*}[\mathrm{~kg}]$ & $\mathrm{e}^{*}\left[\mathrm{~m} / \mathrm{s}^{2}\right]$ & ${\text { Capacity } \mathrm{a}_{0}{ }^{*}[\mathrm{~g}]}$ & ${\text { Demand } \mathrm{a}_{0}{ }^{*}[\mathrm{~g}]}^{\mathrm{FS}}$ \\
\hline $1^{\text {st }}$ Mechanism & 0.186 & 434.37 & 0.947 & 0.197 & 0.063 & 3.13 \\
$2^{\text {nd }}$ Mechanism & 0.184 & 425.45 & 0.953 & 0.193 & 0.086 & 2.24 \\
$3^{\text {rd }}$ Mechanism & 0.164 & 883.01 & 0.968 & 0.169 & 0.087 & 1.94 \\
$4^{\text {th }}$ Mechanism & 0.205 & 33.91 & 0.982 & 0.208 & 0.123 & 1.69 \\
\hline
\end{tabular}

